\title{
Eşyaların Mekân Aidiyeti ve Sosyo-Mekânsal Davranışlarla İlişkisi: Sakarya'da Suriyeli Girişimciler
}

\section{The Sense of Place Belonging of Things and Its Relation with Socio-Spatial Behaviour: Syrian Entrepreneurs in Sakarya}

Handan Akyiğit a,*

${ }^{a}$ Dr. Öğr. Üyesi, Sakarya Üniversitesi, Fen Edebiyat Fakültesi, Sosyoloji Bölümü, Sakarya/Türkiye. ORCID: 0000-0002-7619-1638

\section{MAKALE BİLGISI}

\section{Makale Geçmiși:}

Başvuru tarihi: 01 Kasım 2020

Düzeltme tarihi: 23 Ocak 2021

Kabul tarihi: 01 Şubat 2021

\section{Anahtar Kelimeler:}

Kimlik

Aidiyet

Kolektif Bellek

Gündelik Hayat

\section{ARTICLE INFO}

Article history:

Received 01 November 2020

Received in revised form 23 January 2021

Accepted 01 February 2021

\begin{tabular}{l}
\hline Keywords: \\
Identity \\
Belonging \\
Collective Memory \\
Daily Life
\end{tabular}

ÖZ

Göçmenlerin toplumsal pratik olarak yaşam alanlarında kullandıkları eşyalar grup içi ve grup dış1 ilișki biçimiyle birlikte sosyalleșme sürecini betimleyen analitik bir kategori olarak ele alınmaktadır. Yerleşim mekânlarında kullanılan eşyalar göçmenlerin tekinsizlik hissiyatını aşabilmek için ve "kültürel beden"i korumada bir direnç aracı olarak da işlev görebilmektedir. Bu manada nitel araştırmaya bağlı olarak saha çalışmasının yürütüldüğü çalışmada Sakarya ilinde yaşamakta olan 16 Suriyeli girişimci ile derinlemesine görüşme yapılmıştır. Çalışmada bulguların tümevarımsal bir yolla yorumlanması tercih edilmiștir. $\mathrm{Bu}$ tümevarımsal bakıș açısı tüm Suriyelileri kapsamamaktadır. Yalnızca araştırılan sınırlı bir grubun entegrasyon sürecini mekân aidiyeti bağlamında ele almaktadır. Bu bağ temel olarak gündelik hayat, kendileme, egemenlik alanı, savunulan alan kavramlarıly ilişkilendirilerek değerlendirilmektedir.

\section{Giriș}

Sosyal bilimler alanında göç ve göçmenlik/mültecilik özelinde ele alınan çalışmalar arasında en çok "entegrasyon" konusu tartışılmaktadır. Bu çalışmalarda özellikle yerel topluluk ile azınlık toplulukları arasında sosyo-kültürel veya ekonomik entegrasyon konusu mültecilerin sorunları, ihtiyaçları ve çözümler özelinde ele alınmaktadır. Konunun bu şekilde ele alınışı entegrasyon konusunu ağırlıklı olarak kurumlar ve kurallar/yasal düzenlemeler özelinde ilerleyen makro ölçekli çalışmaların ağırlık kazanmasına neden olmaktadır. Oysaki Kolukırık ve Özcan'ın (2019) vurguladıkları gibi göçmenlik/mültecilik deneyimini anlayabilmek için bireylerin gündelik hayatlarını anlamaya çalışan bunun içinde mikro ölçekli araştırmaların yapılması gerekmektedir. Çünkü bireylerin gündelik yaşam pratiklerini gerçekleştirme sürecinde göç eden bireylere sunulan -de Certeau'nun (2009) deyimiyle- stratejiler yeterli olmayabilmektedir. Stratejiler zamanın tümüne hâkim gibi görünür ancak belli zaman diliminde var olan egemen yapıyı içerdikleri için düzenleyici disiplin mekânizmaları kapsamaktadırlar. Bundan dolayı stratejiler esnek değillerdir

\footnotetext{
* Sorumlu yazar/Corresponding author.

e-posta: hakyigit@sakarya.edu.tr
} 
ve iktidarın devamlılığına bağımlı eylem bütünlüğünü içermektedir. Göç eden bireyler kendilerine sunulan stratejiler karşısında gündelik yaşam sürecinde karşılarına çıkan sorunları, sıkıntıları aşabilmek için taktikler üretek entegrasyon sürecini yaşamaktadırlar. Taktikler kurumsal ve mekânsal olarak belirli sınırları olmayan esnek eylemleri içermektedir. Taktikler stratejilerin içine sızarak bireyin gündelik hayatının birçok alanına entegre olabilmeyi sağlayabilmektedir (de Certeau, 2009, s. 112-113).

Ulus aşırı göç haraketliliğin gittikçe artması beraberinde farklılıklarla bir arada barış içerisinde yaşamanın sıkça tartışılmasını gündeme getirmektedir. Sakarya ise bu konuda önemli bir örneği temsil etmektedir. Zira Sakarya ilinin toplumsal yapısında birçok farklı göçmen ve etno-kültürel gruplar yer almaktadır. Bu kültürel çeşitlilik bir zenginlik olarak algılanmakla birlikte halkın birbirleriyle uyum içerisinde yaşadığı da görülmektedir. Kente göç eden gruplar dönem dönem farklı istihdam politikalarına dâhil edilerek yerleşim yerlerinin ve semtlerinin oluştuğu görülmektedir (Şan ve Akyiğit, 2017). 2011 y1lından itibaren ise Suriye'den Türkiye'ye göç eden mültecilerin Sakarya'nın belli yerleşim yerlerinde ağırlıklı olarak yoğunlaşarak kendi etnik (sosyal) sermayelerine bağlı bir "sokak sermayesi" oluşturmaya başladıkları görülmektedir. $\mathrm{Bu}$ durum gündelik hayat içerisinde mekân aidiyeti üzerinden "biz", "yabancı", "öteki" olarak tanımlanan topluluklarla "sınır" çizilmesine neden olabilmektedir. Bu çalışmada entegrasyon sürecinde önemli bir konu olan mekân ve aidiyet ilişkisine odaklanılmaktadır. İlişkisel olarak ele alınan aidiyet konusu temel olarak "Suriyeli işletme sahiplerinin gündelik hayatlarında semboller aracılığıyla nasıl aidiyet bağı kurdukları?" sorusu özelinde tartışılmaktadır. Bu bağlamda mekân-aidiyet ilişkisi özellikle sembol ve kolektif bellek bağlamları aracılığıyla irdelenmektedir. ${ }^{1}$ Çünkü Karaarslan'ın (2014) dikkat çektiği gibi bir yerde kolektif hafizadan bahsediyorsak hafizanın ait olduğu bir mekândan, hafızayı taşıyacak, sürekli yeniden üretecek bir bedenden ve bedensel pratiklerden söz etmek gerekmektedir. Çalışmanın temel problemi "ben" ve "öteki", "biz" ve "onlar" gibi ayrımların mekânların kullanım ve tasarımlarıyla da şekilleniyor olmasıdır. Mekânsal aidiyetinin nasıl bir duygusal bağ ile oluşturulduğu ise Connerton'un (2012) egemenlik, kendileme alanı ile savunulan alan kavramları aracılığıyla ele alınacaktır. Bu bağ aynı zamanda de Certeau'cu bir okumayla mikro direnç göstergeleri olarak ele alınarak değerlendirilecektir.

\section{Mekân-Aidiyet İlişsisinde Semboller ve Kolektif Bellek}

Gündelik hayatımızda devamlı içinden geçtiğimiz, devamlı kullandığımız yol güzergâhları veya alışveriş yaptığımız, ihtiyaçlarımızı karşılamak için uğradığımız vakit geçirdiğimiz mekânlarda farkında olmadığımız ya da gördüğümüz halde bize değmeyen birçok sembol vardır. Aslında bizler için önemli olmayan bu mekânlar sahiplerinin kendilerini dünyaya açtığı, sembol ağlarıyla ördüğü ve kendilediği dolayısıyla ideolojilerini tanımladıkları ve hatta dünyaya bir manifesto gibi ilan ettikleri küçük mekânları olabilir. "İnsanın uzantısı olan sembollerle örülmüş olan bu mekânlar aynı zamanda kolektif kimliğin bir uzantısıdır.
Özneler tarafindan örgütlenmiş bu mekânlar aslında her birimizin kolektif belleğinden geçer" (Başaran İnce, 2016, s.196). Mekân bireylerin gündelik yaşamındaki sosyal etkileşimlerini kimlerle konuşup kimlerle konuşamayacaklarını birbirlerine karşı nasıl davranması gerektiğini hatırlatırlar (Hopkins ve Dixon, 2006). Bireylerin iletişim ağına ve çevresine bağlı olarak bellek ve hatırlamanın mümkün olduğunu ifade edilmektedir (Assmann, 2001, s. 39-40). Dolayısıyla kolektif bellek sosyalleşme sürecinde farkında olduğumuz ya da olmadığımız akışkan süreçte oluşmaktadır. Gerçekliğin doğası ise "insan imgelemeninin bir yansıması", sosyal inşa, sembolik bir söylem alanı, somut bir süreç ve son olarak somut bir yap1 olarak kavranabilir (Morgan ve Smircich, 1980'den akt. Başaran İnce, 2006, s. 196). Bu tartışmalar aynı zamanda Mead'in (1972) zihnin toplumsal süreç içinde, somut toplumsal etkileşimler matrisi içinde ortaya çıkan ve gelişen bir şey olarak görmemiz gerektiğine yönelik açıklamalarını hatırlatmaktadır. Bundan dolayı hatıraların korunma ya da sergilenme biçimi belleğe dair analitik açıklamayı içeririr. Bu açıklamaların tümü, fiziksel ya da muhayyel bir mekânın, kültürün göndermesinden kaçamaz. Burnett'in (2007) vurguladığı gibi mekânlarda yer alan imgeler insanın doğasını yansıttığı kadar insanlar tarafında yaratılan, tarihsel süreçte işlenmiş kültürel örüntülerinde yansımasını içermektedir. Çünkü "yerler, tarihler, dil, ritüeller, sözcükler ve bireyler gibi şeylerle veya dahil olunan toplumların manevi ve maddi tüm yaşamlarıyla gerçekleşir" (Connerton, 2014, s. 60). Appadurai'nin (1998, s. 182) belirttiği gibi kolektif belleğin ve sembollerin göç eden bireylerin kendilerine yeniden "yer kurma" ve "yerellik üretimi”nde önemli bir bağı vardır. Bu noktada önemli olan tekinsizlik hissiyatı yaşayan göç eden bireyin bu duygusunu aşabilmek için kullanmış oldukları sembollerin Williams'ın (1993) dikkat çektiği gibi "nasıl bir duygu yapısını temsil ettiğini?” okuyabilmektir. Çünkü sembollerin göç eden birey için anlamı mekân aidiyetini kurma biçimlerini anlayabilmemizi sağlayacaktır. "Karşılaşılan her nesne ve onun bütün içerisinde kapladığı yer bize bir çok insan için ortak olmanın bir yolunu hatırlatır ve bu kümeyi incelememiz dikkatimizi onun her bir bölümüne yöneltmemiz bir kaç grubun katkılarının bir birine karıştığı bir düşünceyi parçalara ayırıp incelemeye benzer" (Halbwachs, 2017, s. 140). Bu bakış açısı mekân aidiyetinin yorumlanmasının aynı zamanda gruplar arasında var olan ilişkilerin sosyal, kültürel ve tarihi zeminde konumlandırarak okunması gerektiğininde önemli olduğunu hatırlatmaktadır. Connerton (2012: 20-23) mekân ve toplumsal bellek arasında karşılıklı bir ilişki olduğunu ve belleğin hatırlama ile yapılandığını bundan dolayı da mutlaka bir mekâna tutunduğundan bahsetmektedir.

Lefebvre'nin (1995, s. 25) "gündelik hayat, [...] tekrarların bir araya geldikleri bir mekân mı?" sualinde dikkat çekmeye çalıştığı gibi bireylerin dünyaya dair deneyimleri sürekli ve bütünlüklü bir deneyimdir. Dolayısıyla "kolektif bellek kuşaklararasında zamansal devamlılık sağladığı için topluluğun paylaşılan semboller etrafinda birlikte hareket edebilmesini kolaylaştırır" (Gross, 2002, s. 344). Kimliğin bir bellek birimi olduğunu ve yurt anılarını oluşturduğunu ifade eden Morley ve Robins (1997, s. 130-131) ise mekânın ister ev, ister ofis ya da işletme yeri olsun metaforik

\footnotetext{
${ }^{1}$ Sembollerin kimlik ve aidiyet pekiştirici etkisi üzerine yapılan örnek bir çalışma için bkz. Rose, 2002.
} 
içeriğiyle vatana, kökene gönderme yapacağı gibi yeni yerleşim yerine de gönderme yapar. Çünkü "kolektif bellek bireyin içinde bulunduğu toplumsal yapısı kültürel örüntülerine bağlı olarak sürekli yeniden şekillenmektedir" (Jedlowski, 2001, s. 30). Açık bir şekilde kolektif bellek bireysel içeriğiyle değil, toplumsal bağlamıyla ele alınmaktadır. "Kültürel beden" olarak kolektif bellek geçmiş ile bağlantısal olarak düşünülsede kendini şimdiki zaman içinde güncellemektedir. Kolektif bellek hatırlamak kadar unutuşlarla da kendisini yeniden kurmaktadır. "Belleğimizi etkileyen bir şeyi ya da eylemi kavramak, onu olabileceklere ilişkin bir beklentiler sistemi içinde bir yerlere yerleştirmektir. Sınırları zaman içindeki deneyimlerimize göre çizilen kavrama dünyası, anımsamaya dayanan örgütlü bir beklentiler kümesinden oluşur" (Connerton, 2014, s. 16). Bundan dolayı göç eden bireyler zamansal olarak geçmişte kalanı ve mekânsal olarak geride bıraktıklarını hatırlamak için ağırlıklı olarak materyal kültürel/geleneksel ürünlerden faydalanırlar. $\mathrm{Bu}$ metaryaller bireylerle birlikte taşınarak belleği devamlı olarak besleyen ögeler olarak yer alırlar (Tolia-Kelly, 2004, s. 315). Ancak geçmiş ve geride kalana ait olan belleği besleyen bu metaryaller Jedlowski'ye (2001, s. 31) göre bir “depo" işlevi görmemektedir. Bu materyaller bireyle birlikte taşınırken aynı zamanda kendisini devamlı güncellemektedir. Hatırlamalarla olduğu kadar unutma ile de yeniden inşa edilerek anlam ve biçim değiştirebilir. Burada ise "göç eden bireylerin bellek izlerinin biriktirdiği yerin neresi olduğu?" sorusu çıkar karşımıza. Tolia-Kelly’e (2004, s. 317) göre bu "ev" dir. Bu ev sabit belli bir coğrafyada yer alan bir mekâna gönderme yapmamaktadır. Çünkü göç eden birey için ev metaforik olarak belleğiyle yeniden inşa edilen süreklilik kazanan zamansal bağla uyumlanabilen bir mekândır. De Certeau'nun (2009) ifade ettiği gibi göçmenler tarafindan mekân, ailevi kültürel pratiklerle yeniden düzenlenerek egemen/yerel kültüre bir şekilde direnen, alternatif yaşam taktikleri üretmektedir. Göç eden bireylerin yerleşim mekânlarında kullanmış oldukları semboller bu taktikler arasında yer almaktadır. Yerleşim mekânlarında kullanılan semboller tekinsizlik hissiyatını aşabilmek için ve "kültürel beden"i korumada bir direnç aracı olarak işlev görebilmektedir. Gündelik hayatta bu direnç araçları bireylerin habituslarının -Bourdieu'nun ifadesiyleyansımasını içermektedir. Habitus, bireysel pratiklerin toplumsal boyutuyla ilişkilendirilerek açıklanmasıdır. Bourdieu'ya göre habitus aracılığıyla bireyler kendileri çok da farkında olmadan gerçekleştirdikleri uygulamalarla geçmişin bir yinelemesini ya da önceden sezilen bir dünyayı ortaya koymaktadırlar. Bu bağlamda habitus direnç aracı olarak kendisini beğeniler, hisler, tercihler, belirli tarzda davranmaya yönelik amprik eğilimler, aktörlerin sahip olduğu bir çeşit dünya görüşü ya da kozmoloji olarak çıkabilmektedir (Smith, 1982, s. 88). Örneğin mekân ve toplumsal düzen, özellikle göç eden bireyler için, kültürel kimliğin yaşam alanına yansıtılarak sosyal konumun korunmasında aracı bir form olarak işlev gördüğü ifade edilmektedir (Bachelard, 2014). Bu temel tartışmalar ekseninde makalede mekân-aidiyet ve bellek ilişkisi bir direnç aracı olarak evden ziyade bireylerin yerel halkla daha çok etkileşim içerisinde olmasını sağladığı için işletme mekânları özelinden giderek yorumlanması tercih edilmiştir. Aynı zamanda Suriyeli girişimcilerin işletmelerinde yer verdikleri eşyaların entegrasyon sürecini betimleyen sosyal mekânsal davranışlarla ilişkisi anlamaya çalışılmıştır. Çünkü gündelik hayatta mekânsal pratiklerin açığa çıkmasında, farklılaşmasında göçmenlerin kamusal alanda yerel halk ile etkileşim süreçlerini etkileyen mekânların etkisi oldukça önemlidir.

\section{Araştırmanın Metodolojisi}

Nitel araştırmaya bağlı olarak saha çalışmasının yürütüldüğü bu çalışmada Sakarya ilinin Serdivan ve Adapazarı ilçesinde 9, Karasu'da 3, Akyazı'da 1, Erenler'de 1 ve Sapanca'da 2 olmak üzere toplamda 16 Suriyeli küçük işletme sahibiyle derinlemesine görüşme yapılmıştır. Görüşülen işletme sahiplerinin yaş aralığ 22 ile 66 iken, görüşülen 3 kişi kadın, 13 kişi ise erkektir. Görüşmeler 2019 yılının Temmuz ayında görüşmecilerin iş yerlerinde gerçekleştirilmiştir. Yerinde gözlem ve yarı yapılandırılmış mülakat tekniği ile kullanılarak saha çalışması tamamlanmıştır. Gözlem tekniğiyle bireylerin işyerlerinde kullandıkları sembollere yükledikleri anlamlar yorumlanmıştır. Katılımcılara ulaşılırken "amaçlı örnekleme" yöntemlerinden "kartopu örnekleme"siyle birlikte "maksimum çeşitlilik" örneklemesi kullanılmıştır. Saha araştırması esnasında kartopu örneklem tekniğinden kaynaklanabilecek, birbiriyle örtüşen sonuçlara ve benzer özellikleri olan örnekleme ulaşma riskinin önüne geçebilmek için farklı başlangıç noktaları tercih edilerek farklı meslek kollarına ulaşmaya dikkat edilmiştir. Araştırmada görüşmeler, gönüllülük esaslı olarak gerçekleştirilmiştir. Katılımcıların kendilerini rahat hissetmeleri ve araştırmacıya güvenmeleri için görüşmelerde özne/nesne ilişkisinden kaçınılarak hiyerarşik olmayan bir ilişki çerçevesinde saha çalışmasının gerçekleştirilmesine özen gösterilmiştir. Araştırmanın en temel sınırlılığı araştırmacının katılımcıların kültürel dilini bilmemesinden kaynaklanmıştır. Ancak katılımcılar uzun süredir Türkiye'de ikamet etmeleriyle birlikte esnaf olmalarının etkisiyle Türkçeyi aktif bir şekilde konuşabildiklerinden saha çalışması esnasında iletişim kurabilme açısından bir sıkıntı yaşanmamıştır. Ayrıca görüşme esnasında katılımcıların özellikle duygularını aktarmaya çalışırken zorlanma ihtimali göz önünde bulundurularak istedikleri zaman kendi ana dillerini kullanmayı tercih etmelerini ve kendilerini daha rahat ifade edebilmelerini sağlayabilmek amacıyla görüşme esnasında rehberlik görevi görebilecek Arapça ve Kürtçe bilen anahtar bir kişiden de yardım alınmıştır. Öncelikle Serdivan ilçesinde uzun süredir lokantacılık deneyimi olan ve oldukça tanınan Suriyeli işletme sahibiyle iletişime geçilmiştir. İşletme sahibi birkaç kez ziyaret edilerek sohbet edilme firsatı yakalanmıştır. Böylelikle çalışmanın örneklemini oluşturacak olan diğer işletme sahiplerinin bilgisi de alınarak süreç ilerledikçe elde edilen isimler kartopu gibi büyüyerek örnekleme ulaşılmıştır. Her işletme mekânında yer alan sembollerin mekân-aidiyet ilişkisini daha iyi gözlemleyebilmek amacıyla belirlenen her bir işletme mekânı en az iki kez ziyaret edilmiştir. İşletme mekânı sahipleriyle sosyal bir bağın kurulması sağlanmıştır. Araştırma sorularının sorulması, mekânda yer alan sembollerin aidiyet bağının oluşumundaki yerinin anlaşılması sohbet eşliğinde gerçekleştirilen görüşmeler aracılığıyla sağlanmıştır. Sosyal ilişki ağının kurulmasına dikkat edilmesinin temel nedeni Suriyelilerin araştırmacıya olan güvensizliğini ve özel hayatlarının deşifre edilmesine yönelik kaygılarını ortadan kaldırmaktır. Görüşmede ilk olarak örneklem grubunun yaş, eğitim durumu gibi demografik özellikleri üzerinde durulmuştur. Daha sonra katılımcılara ilk olarak yaşadıkları şehire, işletme 
mekânlarına yönelik düşünceleri ve bunu nasıl anlamlandırdıklarına dair sorular sorulmuştur. Gündelik hayatta mekânsal aidiyetin kolektif bellek ilişkisini açığa çıkartabilmek için işletmelerde kullanılan sembollerin tek tek "işletme mekânında nasıl?, nerede?" yer aldıkları not edilmiştir. Sembollerin sosyo-mekânsal davranışlarla ilişkisel bağını açıklamak için ayrıca bilişsel haritalama tekniğinden faydanılmıştır. Bilişsel haritalama "bireyin günlük yaşantısında karşılaştığı mekânsal çevrede edindiği göreceli konumların ve olgusal niteliklerin kazanıldığı, depolandığ1 ve hatırlandığı bir dizi psikolojik dönüşümün bir araya gelmesiyle oluşan bir süreç" (Ülker Yıldız, 2009'dan akt. Özdağoğlu, 2010, s. 3) olarak ifade edilmektedir. Bu bağlamda Suriyeli işletme mekânında yer alan sembollerin listesi Tablo 3'de gösterildiği gibi not edilerek sembollerin mekânlarda yer verilme yoğunluklarının ve biçimlerinin analitik kategorisine ulaşılmıştır. Böylelikle katılımcıların bilişsel alanlarında sembollerin yer alma biçimi aracılığıyla aidyet ve sosyo-mekânsal davranış ilişkisisi ele alınmıştır. Sembollere ilişkin tutulan notlar ve işletme sahiplerinin sembollere yönelik yapmış oldukları yorumlar, sembollerin mekânlarda kaç kere kullanıldığı dikkate alınarak semboller kendi içerisinde gruplandırılarak tematik içerik analizi yapılmıştır. Tematik içerik analizinde hazır bir kod/kavram listesi kullanılmamıştır. İşletme mekânlarında gerçekleştirilen görüşmeler esnasında yapılan gözlemler esnasında sembollere ilişkin elde edilen veriler, kendi iç bütünlüğünde değerlendirilmiştir. Daha sonra elde edilen veriler çalışmanın temel amacı doğrultusunda kendi içinde anlamlı, ilişkisel bölümlere ayrılarak kodlamalar yapılmıştır. Böylelikle semboller, milliyetçilik içerikli semboller (Türk bayrağı, Suriye Bayrağı, Osmanlı tuğrası, harita), dini inanç ve gelenek içerikli semboller (fotoğraf, ayet, nazar boncuğu, tütsüler, minyatürler) ve toplumsal cinsiyet içerikli semboller (futbol, tespih) olarak üç bölümde incelenmiştir. $\mathrm{Bu}$ semboller aracılığıla Suriyeli işletme sahiplerinin yorumları da göz önünde bulundurularak kolektif bellek, mekân-aidiyet bağı ilişkisi Şekil 1' de gösterildiği gibi tartışılmaktadır.

Şekil 1. Mekânsal Aidiyetin Gündelik Hayat, Kolektif Bellek ve Semboller Özelinden İrdelenmesine Yönelik Diyagram (Times New Roman olarak değiştirdim yazıları)

\begin{tabular}{|l|l|l|}
\hline \multicolumn{1}{|c|}{$\begin{array}{c}\text { Gündelik Hayat ve Sosyo- } \\
\text { mekânsal Davranışlar } \\
\text { i- Kendileme } \\
\text { ii-Egemenlik alanı } \\
\text { iii-Savunulan alan }\end{array}$} & $\begin{array}{l}\text { Bireysel - Kolektif Bellek } \\
\text { Semboller }\end{array}$ \\
Anlamlar, \\
Göstergeler, \\
Sinırlar, \\
Odak noktalar
\end{tabular}

Çalışmada alandan elde edilen veriler doğrultusunda tümdengelimsel bir bakış açısından ziyade tümevarımsal bir yolla bulgular yorumlanmıştır. Bu tümevarımsal bakış açısı tüm Suriyelileri değil yalnızca araştırılan sınırlı bir grubun mekân-aidiyet ilişkisini içerdiğinin altının çizilmesi gerekmektedir. Elde edilen bulgular ve gözlemler gündelik entegrasyon sürecini ve mekân-aidiyet ilişkisini anlayabilmek için işletme mekânlarında yer alan sembollerin kolektif bellek alanına adım atabilmede önemli bir aracı olmuşlardır.

\subsection{Araştırma Sahası: Sakarya'da Kent Mültecileri ${ }^{2}$ ve Girişimcilik Faaliyetleri}

Sakarya Esnaf ve Sanatkârlar Odaları Birliği'ne kayıtlı, Kasım 2019 verilere göre Sakarya'da 3'ü kadın olmak üzere toplam 46 Suriyeli girişimci esnaf bulunmaktadır. Şekil 2'de gösterilmeye çalışıldığı gibi Sakarya' da bulunan Suriyeli Esnafların ilçelere göre dağılışı şu şekildedir: 27 esnaf Adapazarı ilçesinde, 7 esnaf Karasu ilçesinde, 4 esnaf Akyazı ilçesinde, 2 esnaf Erenler ilçesinde, 2 esnaf Hendek ilçesinde, 2 esnaf Sapanca ilçesinde, 1 esnaf Arifiye

\footnotetext{
${ }^{2}$ Koyuncu (2020) Suriyelilerin bulundukları yerden göç etme nedenleri göz önünde bulundurarak "göçmen" kavramının dolayısıyla "göçmen girişimciliği” kavramı temelinde ele alınmasının teori ve pratikte yapısal sorunlara neden olduğunu belirtmektedir. Çünkü Suriyelilerin göç etme eylemini kendi özgür iradeleriyle almadıklarını, zorlayıcı dış faktörlerin
}

ilçesinde, 1 esnaf Pamukova ilçesinde ve 1 esnafta Ferizli ilçesinde bulunmaktadır.

Şekil 2. Sakarya'da Bulunan Suriyeli Girişimcilerin İlçelere Göre Dağılıș1

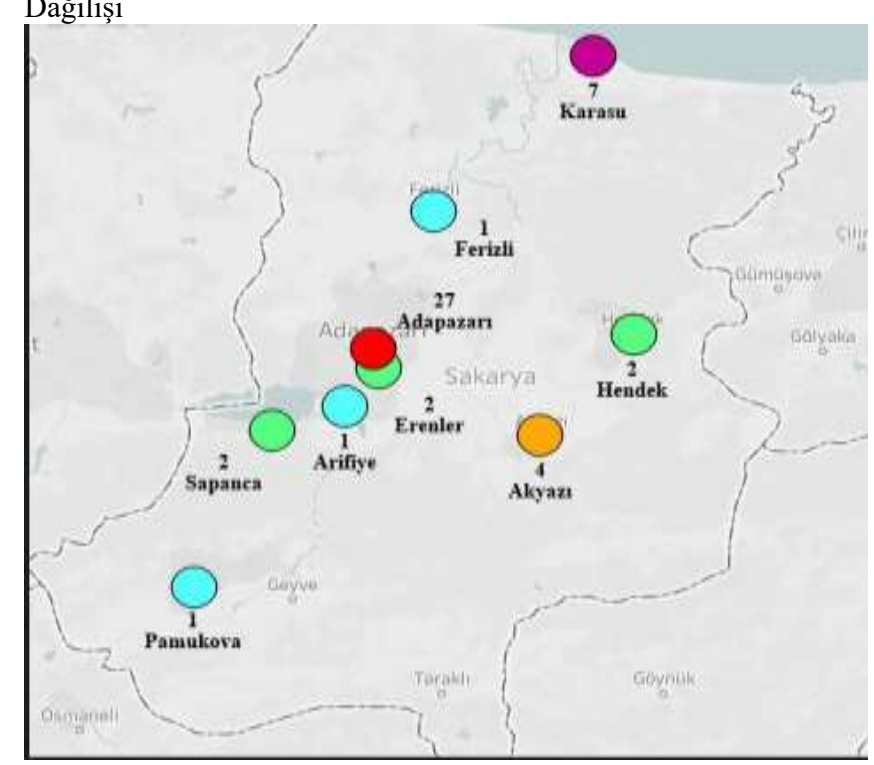

müdahalesi olduğunu belirtmiștir. Ayrıca UNHCR (1995) açıklamasında göç eden ve kentte yaşamına devam eden mülteciler "kent mültecisi" olarak adlandırılmaktadır. Bu nedenlerden dolayı çalışmada Suriyeli işletme sahiplerinden bahsederken mülteci girișimci, kent mültecisi kavramlarının kullanımı tercih edilmiştir. 
Sakarya' da bulunan Suriyeli esnafların mesleklere göre dağılışı ise şu şekildedir: 18 esnaf bakkallık mesleğini, 6 esnaf erkek berberliği mesleğini, 4 esnaf telekomünikasyon cihazları onarımı mesleğini, 3 esnaf lokantacılık mesleğini, 2 esnaf elektrik tesisatçılığı mesleğini, 2 esnaf kuruyemiş imalatı mesleğini, 2 esnaf pastanecilik mesleğini, 1 esnaf manavlık mesleğini, 1 esnaf konfeksiyonculuk mesleğini, 1 esnaf halı yıkama hizmetleri mesleğini, 1 esnaf emlakçılık mesleğini, 1 esnaf terzilik faaliyetleri mesleğini, 1 esnaf kasaplık mesleğini, 1 esnaf tekstil baskıcılığı mesleğini, 1 esnaf çelik eşya imalatı mesleğini ve 1 esnaf ise kuaförlük mesleğini yürütmektedir. İşletmelerin ağırlıklı olarak temel gıda, ihtiyaçları karşılayacak türde olduğu görülmektedir.

Saha çalışması kapsamında görüşme yapılan Suriyeli girişimcilerin 3'ü kadın, 13'ü erkektir. Araştırma kapsamında Sakarya'da işletme sahibi olan kadınların hepsine -3 kişi- ulaşılmıştır. Katılımcıların yaş aralıkları 2266 iken bunlardan 4'ü bekardır. Sakarya'da işletme faaliyet süreleri ise ağırlı olarak 3-4 yıl olmak üzere genel olarak 1 ve 6 yıl arasında farklılık göstermektedir. Katılımcıların gerçekleştirdikleri işletme türü ise berber, bayan kuaförü, elektirik tesisat1, emlak, berber, konfeksiyon, lokanta, pastane, halı yıkama, manav ve kuruyemiş imalatı olmak üzere çeşitlilik göstermektedir. Tablo 1'de saha çalışması kapsamında görüşülen Suriyeli işletme sahiplerinin demografik özellikleri yer almaktadır. Suriyeli işletme sahiplerinin bu mesleki dağılımındaki çeşitlilik ve oran Vuddamalay'in (2018) kitlesel göç dalgası sonucunda açığa çıkan işletme mekânlarına yönelik açıklamalarını hatırlatmaktadır. Ona göre mültecilerin tercih ettikleri çalışma alanları göç ettikleri mekânları sadece barınacak yer sağlayabilecekleri bir yerleşim alanına dönüştürmemektedir. Örneğin etnik yiyecek dükkânlarının açılması göçmenlerin mekânsal varlığının yoğunlaşmasına katk1 sunarken; tekstil, temizlik hizmetleri, pazarcılık gibi tüketim ürünlerinin ortaya çıkması yeni ve kalıcı bir yaşam alanına geçtiklerini temsil etmektedir (akt. Eser, 2018, s. 179).

Tablo 1. Suriyeli Mülteci Girişimcilerin Demografik Özellikleri

\begin{tabular}{llllll}
\hline & Yaş & $\begin{array}{l}\text { Medeni Durum- } \\
\text { Cinsiyet }\end{array}$ & $\begin{array}{l}\text { Türkiye'de Bulunma } \\
\text { Süresi }\end{array}$ & İşteki Faaliyet Süresi & İşletme Türü \\
\hline K1 & 35 & Evli- Erkek & 5 & 3 & Berber \\
\hline K2 & 25 & Evli-Kadın & 6 & 1 & Bayan Kuaför \\
\hline K3 & 27 & Bekar- Erkek & 5 & 2 & Elektirik \\
\hline K4 & 27 & Bekar- Erkek & 5 & 6 & Emlak \\
\hline K4 & 66 & Evli- Erkek & 8 & 5 & Bakkal \\
\hline K5 & 53 & Evli- Erkek & 7 & 4 & Bakkal \\
\hline K6 & 47 & Evli- Erkek & 7 & 4 & Bakkal \\
\hline K7 & 28 & Bekar- Erkek & 6 & 3 & Lokanta \\
\hline K8 & 36 & Evli- Erkek & 4 & 3 & Halı Y1kama \\
\hline K9 & 46 & Evli- Erkek & 5 & 3 & Pastane \\
\hline K10 & 52 & Evli- Kadın & 6 & 2 & Bakkal \\
\hline K11 & 49 & Evli- Erkek & 5 & 1 & Konfeksiyon \\
\hline K12 & 38 & Evli- Kadın & 5 & 2 & Berber \\
\hline K13 & 37 & Evli- Erkek & 5 & 2 & Berber \\
\hline K14 & 22 & Bekar- Erkek & 4 & 3 & Manav \\
\hline K15 & 48 & Evli- Erkek & 5 & 4 & Kuruyemiş imalat1 \\
\hline K16 & 63 & Evli- Erkek & 6 & & \\
\hline
\end{tabular}

\section{Bulgular ve Yorum}

\subsection{Belleğin Yeni Yurdu: Sakarya}

Mekân-aidiyet ilişkisine yönelik yapılan birçok araştırmada göç eden bireyler için "yere bağlılıkla" ilgili yaklaşımlarını etkileyen en önemli unsurlar arasında "güven" olgusunun önemli ölçüde vurgulandığı görülmektedir. Çünkü yer kimliğinin, bireylerin kendi değerlerini, ilişki ağlarını ve deneyimlerini mekân aracılığıyla ifade edebilecekleri önemli bir referans noktası olarak işlev gördüğü ve bu bağlamda güvenlik duygusunun etkili olduğu belirtilmektedir (Dixon ve Durrheim, 2000; Lewicka, 2010; Brown, Perkins ve Brown, 2003). Bu çalışmada da görüşme gerçekleştirdiğimiz Suriyeli işletme sahiplerinin göç etme sebepleri "güvensizlik ortamı" olarak tanımlayabileceğimiz ortak bir sorunu temsil ettiğini göstermektedir. "Güvensizlik ortamı" olarak tanımlanan durum ise genel olarak göç edip geldikleri topraklarda var olan çatışma ortamı, ölme korkusu ve gelecek kaygısıdır.

Türkiye'ye göç etme zorunda olmaları nedeniyle her ne kadar ait olduklarına inandıkları yurtlarından, aile bağlarından ve sevdikleri insanlardan zorunlu olarak ayrılsalarda Sakarya bireyler için "güvenlik ortamını" sağlayabilecekleri bir mekân olmuştur. Sakarya'nın tercih edilmesinde güvenlikli bir alan olarak tanımlanmasında "bağ kurucu/bağlayan sosyal sermaye"nin (Gerni, 2013) yani Sakarya'ya daha önce göç eden tanıdıklarının etkisinin olduğunu ifade edebiliriz. $\mathrm{Bu}$ durumun yeni yerleşim mekânına aidiyet bağı kurmalarında önemli bir aracı olduğu katılımcıların ifadelerinden anlaşılmaktadır. Diğer yandan katılımcıların göç etme süreçlerinden girişimcilik motivasyonu ve sektör tercihine ilişkin algıları, düşünceleri ve bunu nasıl anlamlandırdıklarından hareketle yerleşim mekânlarına ilişkin referans kodları ve göstergeleri şu şekildedir:

Tablo 2. Yerleşim Mekânına / İşletmeye Dair Anlamlar

\begin{tabular}{ll}
\hline Yerleşim mekânı & Göstergeler \\
\hline Ontolojik anlam & $\begin{array}{l}\text { Maddi ve manevi anlamda güvende } \\
\text { olmak, Geleceklerini yeniden } \\
\text { kurabilmek }\end{array}$
\end{tabular}

Araştırma kapsamında görüşülen Suriyeli işletme sahipleri işletme mekânlarından ve yaşamakta oldukları evlerden bahsederken ağırlıklı olarak "güvenlikli alan, çatışma ve 
ölüm korkusunun olmadığı yaşam alanı” gibi değerlendirmelerde bulunmuşlardır. Onlara göre yaşam alanı demek geleceklerini yeniden kurabilmekten, kendilerini huzurlu hissederek inancını yaşabilmek anlamına geliyordu. Bu değerlendirmeler mekân-aidiyet ilişkisinde özellikle göç eden bireyler için "güven" duygusunun ne kadar önemli olduğunu göstermektedir.

\subsection{Geçmiş ve Gelecek Arasında Sembol Evreni: İşletme Mekânları}

İşletme sahibi olan Suriyeli girişimciler işletme mekânlarını sadece bir geçim alanı olarak görmemektedirler. Aynı zamanda sosyo-kültürel değerlerini de sürdürebilecekleri bir mekân olarak görmektedirler. Geçmişin önemi zorunlu olarak göç edip geldikleri ait olduklarına inandıkları yerlerden, geniş aile bağlarından zorunlu olarak kopuşlarına bağl1 olarak okunabilir. Suriyeli işletme sahipleri kendilerine yeniden "yurt" edinmeye çalıştıkları Sakarya' da yerel halktan, özellikle dilleri açısından ve yaşamlarını şekillendiren kültürlerininde farklı olduklarının farkındadırlar. Çünkü geçmişleri ve kopup geldikleri yerler farklıdır. Ama yerel halk ile ortak yönlerinin özellikle dini inançları nedeniyle benzer özellikler taşıdığını ifade ederek mekânda yer alan semboller ile bunu göstermeye çalıştıkları dikkat çekmektedir. Suriyeli işletme sahiplerinin Sakarya'yı kendilerine "yeniden yurt" edinme pratiklerinin göstergeleri arasında işletme mekânlarında yer alan semboller de yer almaktadır. Bu mekânlardaki sembollerin repertuarı "yuva" ile "yurt" olarak mekân arasındaki köprüyü nasıl kurmaya çalıştıklarını temsil etmektedir. Halbwachs'ın (2017: 64) ifade ettiği gibi ne kadar kişisel olursa olsun her bellek yoklama işi ve dile getirilmemiş duyguları anımsamamız parçası olduğumuz veya parçası edildiğimiz toplumların maddi ve manevi tüm yaşamlarıyla birlikte gerçekleşir. Suriyeli işletme sahiplerinin ihtiyacı olan güvenlikli alan ortamı kurma çabası, geçmiş ve gelecekle kurulan ilişkinin biyografik sürekliliğii, kolektif bellek ile bütünleştirilerek semboller aracılığıyla mekâna yansıtıldığ1 görülmektedir. Katılımcıların kendi geleneklerini çevrelerini algılama biçimleri işletme mekânlarında kullandıkları sembolleri anlamlandırma biçimlerinde açıkça anlaşılmaktadır. Araştırma kapsamında ziyaret edilen 16 işletmede bulunan sembollere yönelik yapılan tematik içerik analizi neticesinde üç farklı kategori açığa çıkmıştır:

(i) Milliyetçilik içerikli semboller (Türkiye bayrağı, Suriye bayrağı, Osmanlı Tuğrası, harita),

(ii) Dini inanç ve gelenek içerikli semboller (fotoğraf, ayet, nazar boncuğu, tütsüler, minyatürler),

(iii) Toplumsal cinsiyet içerikli semboller (futbol, tespih).
Tablo 3. İşletmelerde Yer Alan Sembollerin Frekans Dağılımı

\begin{tabular}{lll}
\hline & $\begin{array}{l}\text { Frekans } \\
\text { Dağılımı }\end{array}$ & Yer Verildiği Alan \\
\hline Ayet_Dua & 42 & Görünür \\
\hline Nazar boncuğu & 38 & Görünür \\
\hline Osmanlı Tuğrası & 21 & Görünür, Gösterişli \\
\hline Türkiye bayrağ1 & 18 & Görünür, Gösterişli \\
\hline Suriye bayrağı & 11 & Belirgin, Sade \\
\hline Minyatürler & 10 & Arka planda \\
\hline Fotoğraf & 8 & Arka planda \\
\hline Tütsüler & 5 & Arka planda \\
\hline Tespih & 5 & Arka planda \\
\hline Harita & 4 & Oldukça küçük \\
\hline Futbol & 3 & Arka planda \\
\hline Kategorik Toplam & 158 & \\
\hline
\end{tabular}

Tablo 3'de görüldüğü üzere işletmelerde en çok kullanılan semboller sırasıyla din ve gelenek içerikli sembolleri temsil eden ayet ve dua, nazar boncuğu; milliyetçilik temalı Osmanlı tuğrası, Türkiye bayrağı ve Suriye bayrağı olduğu tespit edilmiştir. Sembollere yönelik bu frekans dağılımları sembolerin bilişsel alanda mekân-aidiyet ilişkisinin göstergelerinin yorumlanması açısından önemli bir başlangıç noktasını oluşturmaktadır.

\subsection{Ayetlerden Nazar Boncuğuna Kutsalın ve Koruyucunun Temsili}

İşletme mekânlarında yer alan nazar boncuğunun sosyal ve performatif bellek aracılığıla aktarılan önemli bir temsiliyet aracı olduğu görülmektedir. Ayet, dua ve cevşen gibi dini içerikleri yansitan sembollerin kolektif belleğin önemli bir göstergesi olarak işletme mekânlarında yer aldığ anlaşılmaktadır. Bu sembollerin özellikle mekânın görünen, en göze çarpan yerlerine asılmasına özen gösterildiği dikkat çekmektedir. Nazar ayetinin yanında Bismillahirrahmanirrahim, nazar boncuklu içerikli maşallah yazılarının, saatlerin kapı girişlerinde tezgâh arkalarında ve kasa üzerinde yer aldığı görülmektedir.

Tablo 4. Dini ve Geleneksel Sembollerin Anlamı

\begin{tabular}{ll}
\hline Dini ve geleneksel sembol & Gösterge \\
\hline Nazar Boncuğu & Kazayı belayı def etmek \\
\hline Ayet Dua & $\begin{array}{l}\text { Kazayı belayı def etmek, huzur } \\
\text { ve bereket sağlayıcı, bol kazanç, } \\
\text { hayırlı müşteri }\end{array}$ \\
\hline
\end{tabular}

İşletme sahiplerinin etnik ekonomik ağlarına bağlı olarak kurdukları işyerlerinde özellikle dini inanç ve gelenek içerikli sembolleri ön plana çıkartmak istedikleri göze çarpmaktadır. Bu pratik bireysel belleğin "sosyal ben" ile girdiği etkileşimde katılımcıların kendilerini ötekilere açarken Müslüman kimliklerini ve ortak kültürel kodlarını ön plana çıkarma eğilimde olduklarını göstermektedir. $\mathrm{Bu}$ eğilimin açığa çıkmasında aynı zamanda işletme sahiplerinin bulundukları çevrenin muhafazakâr/geleneksel değerlerinin ön planda olmasının da etkili olduğunu ifade edebiliriz.

\section{4. İşletmelerde Bulunan Bayraklar: Banal Milliyetçiliğin Yar1-Profan Sembolleri}

İşletmelerde ağırlıklı olan yer alan diğer bir sembol Türkiye ve Suriye bayraklarıdır. İşletme mekânlarında ağırlıklı olarak Türkiye bayrağının asılı olduğu gözlenmiştir. Kullanım biçimi, görünürlüğü ve büyüklüğü değişse de 
bayrak işletme sahibinin göç edip geldiği mekâna, "yeni vatan" a olan bağlılığını, sadakatını gösteren bir sembol olma işlevini görmektedir.

Tablo 5. Milliyetçilik İçeren Sembollerin Anlamı

\begin{tabular}{ll}
\hline $\begin{array}{l}\text { Milliyetçilik içeren } \\
\text { Sembol }\end{array}$ & Gösterge \\
\hline Türkiye Bayrağı & $\begin{array}{l}\text { Sadakat, güven, huzurlu hissetme, yeni } \\
\text { vatan }\end{array}$ \\
\hline Suriye Bayrağı & $\begin{array}{l}\text { Özlem, kökene yönelik aidiyet, ikinci } \\
\text { ev }\end{array}$ \\
\hline Osmanlı Tuğrası & Kutsal devlet \\
\hline
\end{tabular}

Billig'in (2002) Banal Milliyetçilik eserinde yer verdiği gibi bayraklar işletme mekânlarında "selamlanmadan", "sallanmadan" milliyetçiliğin genelleşmesi ve neredeyse görünmez hale geldiği halleri tasvir etmektedir. Böylelikle Suriyeli işletme sahiplerinin millet ve vatana yönelik tasviri gündelik hayatta kullanımının sıradanlığı üzerinden normalleşmektedir. Bayrakların mekânlarda görünür ve yüksek yerlere asıldıkları dikkat çekmektedir. İşletme sahiplerinin anlatılarında özellikle Türkiye bayrağına yer vermelerinin özel bir anlamı olduğu anlaşılmaktadır: “Türkiye'ye yönelik sevgi, devlete yönelik saygı ve sadakat"1n bir göstergesidir. Osmanlı tuğrası işletme mekânlarında dikkat çeken bir diğer objedir. Özellikle işletme mekânlarında Türkiye bayrağının yanında yer aldığ1 gözlenmiștir. Katılımcılara göre Osmanlı tuğrası kuvvetli ve adaletli bir iktidara sahip olan "kutsal bir devletin" sembolüdür. Türkiye bayrağının yanında asılı durmasının temel nedeni Türkiye'yi, kendilerine yönelik sunduğu 1lımlı politik dil ve Osmanlı İmparatorluğu ile özdeşleştirdikleri içindir. Bu ifadeler Cohen'in (1999, s. 32) "bir sembol, duyguları ne kadar güçlü bir biçimde uyarırsa, iktidarı o denli güçlü olur ve o denli işlev kazanır" ifadesini hatırlatmaktadır. Çünkü araştırma sahasının gerçekleştiği Sakarya ilinin muhafazakar sosyo-kültürel dokusu ${ }^{3}$ düşünüldügüunde işletme sahiplerinin bayrağa ve Osmanlı tuğrasına verdikleri bu tür anlamlar Mead'in (1972) sözünü ettiği “yorum süreci”nin, sosyal edimin yarattığı bir "oydaşım” olarak burada devrede olduğunu göstermektedir. Çünkü işletme sahiplerinin gündelik yaşam pratiklerini gerçekleştirdikleri etkileşim halinde bulundukları yerel halkın sosyo-kültürel değerlerini, ideolojik kabullerini içselleştirdikleri ve anlamdırarak yorumladığ görülmektedir. Öyle ki Suriye bayrağının yanında Türkiye bayrağını ya da Osmanlı tuğrasını asmamanın asmaktan daha çok anlamı olduğunu ifade etmektedirler. ${ }^{4}$ Suriyeli işletme sahiplerinin bu tarz anlatılarında sembollerin entegrasyon sürecinde karşı karşıya kaldıkları önyargıları aşabilmek için örtük bir işlev gördüğü rahatlıkla anlaşılmaktadır. Burnett'in (2007, s. 59) ifade etmiş olduğu üzere semboller yalnızca baktığımız seyrettiğimiz ya da dekor amaçlı kullandığımız basit maddi nesneler değildirler; gündelik hayatta bireylerin hislerini etkileyebilen, görme biçimlerini farklılaştırabilen aktif objeler olarak görmemiz gerekmektedir. Bu bağlamda Suriyeli işletme sahiplerinin işletme mekânlarında yer alan milliyetçilik temalı sembollere baktığımızda kendimize

\footnotetext{
${ }^{3}$ Sakarya'nın sosyo-kültürel ve politik yapılanmasına ilişkin genel bir tartışma için bkz. Akyiğit, 2017.

${ }^{4}$ Azınlık grupları tarafından geliştirilen bu tarz taktikler "mağdura uygun davranış" olarak betimlenmektedir. Örneğin Doğan (2019) çalışmasında Suriyeli kadınların ya da erkeklerin yerel halk tarafından kendilerine olumsuz etiketleme söylemlerini gözeterek davranışlarına yön verdikleri belirtilmektedir.
}

sormamı gereken en önemli soru şuydu: "Bayrağın bir işletme mekânında yer alması aslında neyi ortadan kaldırmaya çalışmaktadır?”

\subsection{Hibrit mekânlar: Fotoğraflar, Minyatürler ve Cinsiyet temsili Semboller}

Katılımcıların işletme mekânlarında yer alan Türkiye'yi ve göç edip geldikleri coğrafyayı temsil eden minyatürler, tütsüler ve fotoğraflara ilişkin ifadeleri doğrultusunda kategorize edilen göstergeler ve saha çalışması sürecinde yapılan gözlemler bireylerin yaşadıkları yerle ilişkili geliştirdikleri aidiyet bağının etnik, fiziksel (mimari), sosyo-kültürel ve sembolik anlamlar aracılığıyla kurulduğunu göstermektedir. Sakarya'da birçok etnik merkezli yerleşim alanı bulunmaktadır. Katılımcılarında Adapazarı ve Serdivan semtlerinde benzer şekilde ağırlıklı olarak homojen etno-kültürel yerleşim mekânlarında yaşadıkları dikkat çekmektedir. Ancak Suriyeli kent mültecilerin kısa zamanda bulundukları yeri benimserken eş zamanlı olarak dönüştürdükleri ve kendilerine göre bir "sokak sermayesi" oluşturmaya başladıkları görülmektedir. Göç edip geldikleri yerleri anımsatan figürleri, sembolleri mekânla sentezleyerek kurgulamaları etnik kimliklerini mekânda hibrit bir şekilde sürekliliğini sağladıklarının göstergesidir. Bundan dolayı göçmenlerin etnik kimliklerinin devamlılıklarının sağlanmasında mekânın iki önemli öğeye karşılık geldiğini belirtebiliriz: Unutmamak ve kültürel belleği yaşatmak. Özellikle kadın Suriyeli girişimcilerin mekânlarında toplumsal cinsiyeti temsil eden etnik motifler, şallar objeler dikkat çekerken erkek girişimcilerin mekânlarında ise Türk, Arap motiflerini yansıtan kapı ve tezgâh süslemeleriyle tespihler dikkat çekmektedir. ${ }^{5}$ Yani göçle birlikte yaşamlarını devam ettirebilecekleri ekonomik kazançlarını sağlayan işletme mekânları aynı zamanda göç eden bireyin kimliğini de beraberinde taşıdığının göstergesidir. Kendi ülkesinden getirdiği ya da kendi ülkesini temsil eden objelerle ile kimliğini, dilini ve kültürünü mekânsallaştırarak korumaya çalışmaktadırlar. Bachelard'ın (2014) belirttiği gibi içsel dünyamızın topoğrafyası olan mekân, göç edilen yerde kimlik mekânlarına dönüşmektedir. Nitekim "Ducan toplumsal cinsiyet ilişkilerinin mekânlar aracılığıyla yeniden kurularak bireylerin kendilerini mekân aracılığıyla aktarmasını sağladığını” ifade etmiştir (akt. Zengin, 2011, s. 75). İşletmelerin kimlik mekânlarına dönüşmesi Bourdieu'cu bir ifadeyle- aynı zamanda bireylerin toplumsal alanda konumlanışlarını anlatan ve bu konumlanışlarının toplumsal pratiğini yansıtan habituslarının göstergeleridir. Çünkü bu objeler toplumsal cinsiyeti ve kültürel örüntüleri temsil eden sembolik sermayelerin göstergeleridir. $\mathrm{Bu}$ anlamda habitus'ların işletme mekânlarına yansıma biçimini açıklayabilmek için toplumsal pratik kavramına başvurmak yerinde olacaktır. Toplumsal pratik, dişarıdan bir belirleyici olmaksızın bedenin toplumsal olarak öğrendiği bilgi türüdür (Sancar, 2016, s. 194). Toplumsal pratik olarak objelerin işletme mekânlarında kullanılma biçimi yaşanmakta olunan ilişki

\footnotetext{
5 Benzer sekilde Yeter (2018) Kahramanmarașta Sütçü Imam Üniversitesi'nde okuyan kadın Suriyeli öğrenciler ile gerçekleştirdiği saha çalışması sonucunda bireylerin yerel halkın örtünme, örf ve adetlerine göre davranmaya özen göstererek gündelik yaşamlarına devam etmeye çalıştıklarını ifade etmektedir. Çalışmasında bu değişimi asimile olarak değil aksine yerel halk ile uyumlu yaşamanın bir ön koşulu olarak yorumlandığı belirtilmiştir.
} 
biçimini sosyalleşme sürecini betimleyen analitik kategoridir. Dolayısıyla Suriyeli girişimci mültecilerin işletme mekânlarında hem yerel hem de kendi kişisel tarihlerini temsil eden semboller aracılığıyla bir "yeniden yerellik üretimi" çabası içerisinde olduklarını ifade edebilebilir. Çünkü göç eden birey için kuşkusuz "yurt" olarak benimsemeye çalıştığ 1 , "güvenlikli yaşam alanı" olarak tanımladığı Sakarya ve işletme mekânı sadece temel ihtiyaçlarını karşılayabileceği ontolojik bir alan değildir; "yabancı", “öteki” olarak anıldığı yerleşik alanda yaşamanın yarattığı negatif/olumsuz ön yargılara karşı koyabilmeyi ve kendini tanıtmayı gerektiren bir mekândır.

\subsection{Sembollerin Mekân Aidiyetini Etkileyen ve Sosyo-Mekânsal Davranışlarla İlişskisi}

Mekân aidiyeti sosyolojik altyapı barındırmaktadır. Çünkü birey, içinde bulunduğu toplumun hafızasından etkilenerek kendi bireysel hafizasını kurmaktadır. Sosyo-kültürel etmenler ve bu etmenlerin mekân davranışları üzerindeki etkileri özellikle kullanılan semboller aracılığıyla mekân aidiyetinin okunmasını sağlamaktadır. Connerton (2012, s. 14) mekân ile kolektif bellek arasında bir bağ olduğunu ve mekândaki düzenin, kullanılan sembollerin hafizanın yansıması olduğunu belirtmektedir. $\mathrm{Bu}$ manada saha çalışması sürecinde bilinçsel haritalama tekniği aracılığıyla bireylerin anlatılarında "Suriyeli işletme sahiplerinin mekânlarında yer verdikleri semboller aracılığıyla mekân aidiyetini nasıl geliştirdikleri?" sorgulanmıştır. Bu bağ temel olarak kendileme, egemenlik alanı, savunulan alan olarak ifade edilen mekân aidiyetini etkileyen sosyomekânsal davranışlarla ilişkilendirilerek değerlendirilmiştir. Mekân aidiyetini etkileyen bu mekânsal davranış biçimleri gündelik hayat entegrasyon sürecinde De Certeau'nun (2009) ifade ettiği biçimiyle taktikleri ve direnç biçimlerini de ortaya koymaktadır. Çünkü bu taktikler ve direnç hareketleri sıradan insanların gündelik yaşam alanında baskın/iktidar olanın yarattığı egemenlik alanı karşısında bireylere özgürlük alanları yaratmaktadır. Bir özgürlük alanı olarak Suriyeli işletme sahiplerinin işletme mekânlarında yer alan semboller "gündelik hayatta öznelerin pratiklerinde amaçlanmamış niyetlerle ya da taşıdıkları anlamların bile farkında olmadıkları daha derin toplumsal anlamları" (De Certeau, 2009, s. 145) içermektedir. Bundan dolayı özgürlük alanları sıradan toplumsal yaşam hareketliliği içerisinde sessizce kendisini göstermektedir. Direnç taktikleri aracılığıyla mekân-aidiyet ilişkisinin kurulması sağlanabilmektedir.

Suriyeli işletme sahiplerinin mekânlarında kullanmış oldukları semboller ağırlıklı olarak kendileme örneğini temsil etmektedir. Çünkü "kendileme, bireyin yaşamakta olduğu mekâna ya da çalıştığı ofise yaptığı müdahaleler veya yerleştirdiği objelerle kimliğini yansitarak benimsemesidir" (Proshansky, Fabian, \& Kaminoff, 1983). Hemen her işletme mekânlarında yer verilen aile fotoğrafları, göç edip geldikleri bölgeleri temsil eden haritalar, küçük minyatürler, fotoğraflar bunların "mekânın kendilenmesi"ni temsil eden en önemli göstergeleri arasında yer almaktadır. Suriyeli işletme sahiplerinin işletme mekânına yönelik bu müdahalesi Graumann'ın

${ }^{6}$ Benzer şekilde Sakarya'da yaşamakta olan Suriyeli mülteciler özelinde yapılan bir çalışmada bireylerin kendi evlerinde 'Türk gibi olmanın' ötesinde kendi dillerini konuşmayı, yemek kültürlerine göre tüketim
(2002) ifadesiyle yaşamakta oldukları mekâna kendi sosyokültürel değerlerine yönelik izler bırakarak zamanla aidiyet duygusunu geliştirebilecek izler bırakmanın gayretinin göstergesidir. Göç eden bireyler için "bir yeri kendisinin yapma" pratiği ulus ve aidiyet bağlarını kurma olarak algılamak en azından bu çalışmanın kapsam ve sınırlılıkları düşünüldüğünde elbette iddia edilemez. Zira burada ifade edilmek istenilen mekânı kendileme, kendinden iz bırakma pratiği daha çok yaşamakta olduğu mekânda yer edinme pratiğiyle eş olarak düşünülebilir. ${ }^{6}$

Aynı zamanda işletme mekânlarında özellikle dini ve geleneksel ritülleri içeren semboller ile milliyetçiliği temsil eden semboller Suriyeli işletme sahiplerinin kendilerine bir egemenlik alanı yaratmaya çalıştıklarının göstergesidir. Çünkü "egemenlik alanı temel olarak kişinin kendini denetleme hakkına sahip olduğu, olumsuz/negative diş etkenlere karşı savunulan, sınırlara sahip korunan alanları temsil etmektedir" (Proshansky, Fabian, \& Kaminoff, 1983). Suriyeli işletme sahiplerinin bu sembollere yükledikleri anlamlardan yola çıkarak gündelik yaşamlarında karşılaştıkları "negative ayrımcılık" içeren davranışları, ithamları kırabilmek için kullanmayı tercih ettiklerini ifade edebiliriz. Bundan dolayı bu semboller aracılığıyla yaratılan "savunulan alan" yerel halk ile "sembolik sınırları" aşabilme çabasının göstergesidir. Özellikle Suriyeli işletme sahiplerinin mekânlarında bulunan gösterişli, yoğun Türkiye Bayrağı ve Osmanlı Tuğrası kullanımı yerel halk ile "sembolik sınırları" aşabilmek için kullandıkları önemli bir kimlik obsesyonu olduğu ifade edilebilinir. Ayet, dua ve nazar boncuğu içerikli objeler/yazılar kendi dini inançlarının, kültürel örüntülerinin temsili olmasına rağmen işletme mekânlarında yer verme nedenleri bölgede hâkim olan Müslüman-Türk kimliğiyle ilişkisel bağ kurma çabasının bir yansımadir.

Sonuç olarak zamansal ve mekânsal anlamda Suriyeli işletme sahipleri açısından 'yersiz'liğin olmadığı açıktır. Zira bireyler her koşulda bir yerdedirler ve bir zaman içinde yaşamlarına devam etmektedirler. İçinde yaşamakta oldukları yeni mekânlarda zamanla gelişen bir ilişki ağ içerisindedirler. Suriyeli işletmecilerin anlatılarında doğup büyüdükleri coğrafyanın artık geçmişte kaldığ 1 açıktır. Ancak bu geçmişte kalış yok olmayı beraberinde getirmemektedir; işletme mekânını imgelemesiyle yeniden şekil alarak devam etmektedir. Mekânlarda bulunan objeler ve fotoğraflar aracılığıyla geçmiş şimdiki zaman dilimi içerisinde mekânı hem pratik hem de hissî ve fikri olarak çoğaltmaktadır. Bu bağlamda özellikle Suriyeli işletme sahiplerinin saha çalışması süresince gündelik hayatlarını sürdürme pratiklerini ve Sakarya'da da kendi etnik sosyal ağlarına bağlı olarak sokak sermayesi oluşturmaya başladıklarını göz önünde bulundurduğumuzda, Nora'nın (2006) ifade ettiği gibi mekânın kolektif bellek ve semboller aracılığıyla köken kültürü çevreleyen somut sınırlardan ziyade konumlarını belirten "bellek mekânları" nı oluşturduğunu ifade edebiliriz.

alışkanlıklarına devam etmeyi tercih ettikleri ve uydu aracılığıyla kendi TV kanallarını izleyerek bir direnç alanı yaratmaya çalıștıkları ifade edilmektedir (Kırış, 2019). 


\section{Sonuç}

Suriyeli işletme sahiplerinin kolektif belleklerinin bir yansıması olarak mekânlar bireylerin kendilerine dair anlatılarına ilişkin tamamlamayı öngördükleri ve kimliklerini kurmayı tercih ettikleri semboller ile düzenlenmiştir. Mekânın tasarımı, mekâna yapılan müdahaleler Harvey'in (1992) ifade etmiş olduğu gibi geçmiş, şimdi ve gelecek arasında paralel olarak bir bağ kurmanın gizil gücünü açıkça göstermektedir. Çünkü bu bağ mekân-aidiyet ilişkisini kurabilmenin, gündelik hayatta entegrasyonu sağlayabilmenin, bulundukları yerleşim alanında yerli halk ile diyalog kurmanın bir çabanın ürünüdür. Çalışma kapsamında saha deneyiminde yapılan gözlemler ve katılımcıların anlatılarından elde edilen bulgular daha önce Suriyeli işletme sahiplerinin mekâna ilişkin aidiyet ilişkisini besleyen en önemli faktörün başta din olmak üzere kültürel, geleneksel benzerliklerin olduğu açıkça görülmektedir. Gündelik hayat entegrasyonunda bu faktörlerin "kültürel bagaj" (Tabor ve Milfont, 2011) görevi gördüğü açıktır. Suriyeli işletme sahiplerinin Sakarya'yı "güvenlikli bir yaşam alanı" olarak tanımlamaları işletme mekânlarında yer verdikleri milliyetçilik içerikli sembollere yansımaktadır. Ayrıca işletme mekânlarında yer alan hem dinsel hemde geleneksel semboller Suriyeli işletme sahiplerinin habituslarının mekâna yansıtarak biyografik sürekliliği yaşatabilme çabasını göstermektedir. Aynı zamanda yerel halkı ve Türkiye'yi temsil eden milliyetçilik içerikli semboller aracılığıyla yerel halk ile var olan “sembolik sınır”ların yıkılmaya çalışıldığı görülmektedir. Suriyeli işletme sahiplerinin mekânlarında kullanmış oldukları sembollerle kendileme ve savunulan alan yaratma pratikleri mekânın farklı sosyo-kültürel ve politik angajmanları içeren zengin aidiyetler bütünü içerdiğini göstermektedir. Mekâna kendinden iz bırakma pratiği açık bir şekilde kolektif bellek ve semboller aracılığyla zamana ve yeni "yurt" edindiğin mekâna demir atma etkinliğidir. Bu çalışma kapsamında elde edilen bulgular, saha izlenimleri göç eden bireylerin geldikleri yerleşim alanını yeniden yurt edinme süreçlerini anlayabilmek için makro ve mikro düzlemler arasındaki dinamik ilişkiyi göz önünde bulundurarak okunması gerektiğini hatırlatmaktadır. Çünkü gündelik hayat entegrasyonu bireyler arasındaki ilişkilerin yanısıra o toplumdaki kültürel ve tarihsel bağlarla şekillenen ortak kodların, mitlerin ve duyguların beslenmesiyle evrimleşen bir alanı temsil etmektedir. Göç eden bireylerin gündelik hayat entegrasyon süreçlerinde üretmiş oldukları taktikleri görerek okuyabilmenin ve bireysel deneyimlerin izini sürmenin entegrasyon süreçlerinde oldukça önemli bir yeri olduğu açıktır. Katılımcıların anlatılarında açıkça dramatik bir biçimde kendileri için artık "eve geri dönüş"ün mümkün olmadığ1 anlaşılmaktadır. Ancak Suriyeliler için bu durum kendilerine asla yeniden bir yurt edinemeyecekleri anlamına gelmemektedir. Bundan dolayı kendi içlerinde gündelik yaşamlarında yaşamakta oldukları entegrasyon süreçlerinde, karmaşık ağsal iletişim araçlarına, yeniden bir yurt edinme pratiklerine, biyografik ve duygusal motiflerine bakmak önem arzetmektedir.

\section{Kaynakça}

Akyiğit, H. (2017). Türkiye'de Ulus devletin Dönüşüm Sürecinde Etnik Kimlikler: Sakarya İli Örneği. Yayımlanmamış Doktora Tezi, Sakarya Üniversitesi, Sosyal Bilimler Enstitüsü.

Appadurai, A. (1998). Modernity at Large: Cultural Dimensions of Globalization. London: University of Minnesota Press.

Assmann, J. (2001). Kültürel Bellek. Ayşe Tekin çev.. İstanbul: Ayrıntı Yayınları.

Bachelard, G. (2014). Mekânın Poetikası. Alp Tümertekin (çev.). İstanbul: İthaki Yayınları.

Başaran İnce, G. (2016). Gündelik Hayatta Kolektif Belleğin İnşası: Minibüs Sembolleri Üzerine Bir Değerlendirme. içinde Yerli ve Milli Gündelik Hayat, Ankara: İletişim Yayınları.

Billig, M. (2002). Banal Milliyetçilik. Cem Şişkolar (çev.). Ankara: Gelenek Yayınc1lık.

Burnett, R. (2007). Imgeler Nasıl Düşünür? Güçsal Pusar (çev.). İstanbul: Metis Yayınları.

Brown, B., Perkins, D.D ve Brown, G. (2003). Place attachment in a revitalizing neighbourhood: Individual and block levels of analysis. Journal of Environmental Psychology, 23, 259-271.

Cohen, A. P. (1999). Topluluğun Simgesel Kuruluşu. Mehmet Küçük (çev.). Ankara: Dost Kitabevi..

Connerton, P. (2012). Modernite Nasil Unutturur?. Kübra Kelebakoğlu (çev.). İstanbul: Sel Yayıncılık.

Connerton, P. (2014). Toplumlar Nasıl Anımsar?.2. Basım, Alaeddin Şenel (çev.). İstanbul: Ayrıntı Yayıncılık.

De Certeau, M. (2009). Gündelik Hayatın Keşfi I; Eylem, Uygulama Üretim Sanatlart. Lale Arslan Özcan (çev.). Ankara: Dost Yayınları.

Doğan, F. (2019). Yabancı İle Bir Arada Yaşama Ve Ötekileştirme: Mardin Halkının Bakışından Suriyeli Sığınmacılar. Yayımlanmamış Yüksek Lisans Tezi, Aydın Adnan Menderes Üniversitesi, Sosyal Bilimler Enstitüsü.

Dixon, J. \& Durrheim, K. (2000). Displacing place identity: A discursive approach to locating self and other, British Journal of Social Psychology, 39, 1, 27-44

Eser, B. (2018). Mülteci Restoranları Gastronomik Sahanın Neresinde? Göçmen Mahalleleri, Mülteci Yemekler ve Mekânsal Ayrışmaya Dair Kuramsal Bir Giriş, ViraVerita E-Journal: Interdisciplinary Encounters, 8, 172-195.

Gerni, M. (2013). Iliş̧kilerin Maddi Yönü Sosyal Sermaye ve Örgütsel Boyutu. İstanbul: Beta Yayınları.

Graumann, Carl F. (2002). "The Phenomenological Approach To People-Environment Studies", Handbook of Environmental Psychology, Robert B. Bechtel And Arza Churchman, New York, By John Wiley \& Sons, Inc.. 
Gross, T. (2002). Anthropology of Collective Memory: Estonian National Awakening Revisited, Trames, 6 (56/51), 342-352.

Halbwachs, M. (2017). Kolektif Hafiza. Banu Barış (çev.). Ankara: Heretik Yayınları.

Harvey, D. (1999). Postmodernliğin Durumu. 2. Basım. Sungur Savran (çev.). İstanbul: Metis Yayınları.

Hopkins, N. \& Dixon, J. (2006). Space, place, and 1dentity: Issues for political psychology. Political Psychology, 27, 173-185.

Jedlowski, P. (2001). Memory and Sociology: Themes and Issues. Time and Society, 10 (1), 29-44.

Karaarslan, F. (2014). Modern Dünyada Toplumsal Hafiza ve Dönüşümü, Yayımlanmamış Doktora Tezi, Selçuk Üniversitesi, Sosyal Bilimler Enstitüsü.

Kolukırık, S. ve Özcan, N. (2019). Farklılık ve Farkındalık Ekseninde Suriyeli Göçmen Nüfusun Sosyolojik Özellikleri: Payas İlçesi Örneği, Göç Dergisi, 6, 2, 191-212.

Koyuncu, A. (2020). Toplumsal Kabulde Ekonominin İmkânı -Konya'daki Suriyeli Girişimciler- İnsan ve Toplum Dergisi. 10 (3), 100-131.

Kırış, E. (2019). Gündelik Hayatın Çoğul Görünümleri: Sakarya'da Yaşayan Suriyeli Sığınmacılar, Yayımlanmamış Yüksek Lisans Tezi, Sakarya Üniversitesi Sosyal Bilimler Enstitüsü.

Lefebvre, H. (1995). The Production Of Space. Donald Nicholson Smith (çev.). Oxford: Blackwell.

Lewicka, M. (2010). What makes neighbourhood different from home and city? Effects of place scale on place attachment. Journal of Environmental Psychology, $30,35-51$.

Mead, G. H. (1972). Mind, Self and Society. London: The Universty of Chicago Press.

Morley, D., \& Kevin R. (1997). Kimlik Mekânları: Küresel Medya Elektronik Ortamlar, Kültürel Sinırlar. Emrehan Zeybekoğlu (çev.). İstanbul: Ayrıntı Yayınları.

Nora, P. (2006). Hafiza Mekânları. Mehmet Emin Özcan (çev.). Ankara: Dost Kitabevi.

Özdağoğlu, A. (2010). Bilişsel Haritalama ve Analitik Serim Sğreci Entegrasyonu, Yönetim ve Ekonomi Dergisi, 17,1, 1-10.
Smith, A. O., 1982. Here There is Life: The social and cultural dynamics of successful resistance to resettlement in postdisaster Peru, in Involuntary Migration and Resettlement: The Problems and Responses of Dislocated People, edited by A. Hansen and A. Oliver- Smith. Boulder, CO: Westview Press. pp. 85-103.

Tabor Aidan S.\& Milfont, T. L. (2011). Migration change model: Exploring the process of migration on a psychological level. International Journal of Intercultural Relations, 35(6), 818-832.

Tolia-Kelly, D. (2004). Locating Processes of Identification: Studying the Precipitates of ReMemory Through Artefacts in the British Asian Home. Trans. Inst. Br. Geogr. NS 29, 314-329.

Proshansky, H. M., Fabian, A. K., \& Kaminoff, R. (1983). Place identity: Physical world socialization of the self. Journal of Environmental Psychology, 3, 5783.

Rose, G. (2003). Family Photographs and Domestic Spacings: A case study. Transnational Institute British Geography, 28, 5-18.

Sancar, S. (2016). Erkeklik İmkânsız İktidar. 4. Baskı. İstanbul: Metis Yayınları.

Şan, M.K. \& Akyiğit, H. (2017). Sakarya'da Yaşayan Farklı Etno-Kültürel Gruplarda Birlikte Yaşama Kültürü ve Aidiyet Mekân İlişkisi, Uluslararası Sakarya Sетроzуити. 679-684.

UNHCR (1995). UNHCR's Policy and Practice Regarding Urban Refugees: A Discussion Paper, Inspection and Evaluation Service. Erişim: http://www.urbanrefugees.org/wpcontent/uploads/2020/08/Discussion-paper-onurban-refugees 1995.pdf

Williams, R. (1993). Kültür. Suavi Aydın (çev.). Ankara: İmge Yayınları.

Yeter, E. (2018). Suriyeli Göçmen Kadınların Dini-Kültürel Kimlik Oluşturmalarında Yerel Dini Kültürün Etkisi: Kahramanmaraş Örneği. ANTAKIYYAT Dergisi, 1 (1) , 99-126.

Zengin, A. (2011). İktidarın Mahremiyeti: İstanbul'da Hayat Kadınları ve Seks İşciliği, İstanbul: Metis yayınları. 


\section{Extended Abstract}

Transnational migration has raised the question of whether people of different cultures and backgrounds can live together in peace. Sakarya is an important example of this phenomenon because it hosts various ethnocultural groups, who live in harmony as they perceive this diversity as cultural richness. Sakarya has witnessed a flux of refugees from Syria since 2011. Those people live in certain parts of the city and accumulate "street capital" based on their ethnic (social) capital. As regards spatial belonging, the accumulation of street capital results in boundaries dividing communities as "us", "strangers" and "others" in everyday life. This study focuses on the relationship between "space" and "belonging" which are important in the integration process. The study adopts a relational approach to the concept of belonging and discusses it in conjunction with the question, "What kind of a sense of belonging do Syrian business owners build through symbols in everyday life? In this context, the study focuses on symbols and collective memory to evaluate the relationship between space and belonging.

The main research problem is that the divide between "me" and "the other" and "us" and "them" depends also on how space is designed and used. We use Connerton's (2012) "territoriality," "communal personalization," and "defensible space" to discuss what kind of an emotional bond determines spatial belonging. We perceive that bond as a sign of micro-resistance and approach it from a Certeauian perspective. We treat the relationship between space-belonging and memory as a means of resistance and focus on Syrian business owners' workplaces rather than their homes. We also try to understand the relationship between workplace furniture and social-spatial behaviors, describing the integration process through which Syrian refugees are going.

This was a qualitative field study. The sample consisted of 16 Syrian small business owners (three women and 13 men) living in the districts of Serdivan and Adapazari $(n=9)$, Karasu $(n=3)$, Akyazi $(n=1)$, Erenler $(n=1)$, and Sapanca $(n=2)$ of Sakarya, Turkey. Participants were recruited using snowball and maximum diversity sampling techniques, which are purposive sampling methods. Data were collected through in-depth interviews conducted at the workplaces of the participants in July 2019 . The mean age was 26 years (min: 22, max: 66). The fieldwork consisted of on-site observations and semi-structured interviews. We observed and interpreted what meaning the participants attached to the symbols in their workplaces. The interviews first focused on demographic data (age, education, etc.) and then on where they lived, what they thought about their workplaces, and what meaning they attached to them. In order to explore the relationship between spatial belonging and collective memory in everyday life, we asked the participants what symbols they had in their workplaces and where those symbols were precisely. We also used cognitive mapping to explain the link between the symbols and socio-spatial behaviors. The notes and the participants' comments on the symbols were analyzed using thematic content analysis based on the frequency of the symbols in the workplaces. A code/concept list was not used for the thematic content analysis. The interview and observational data were evaluated in their own contexts. The data were divided into meaningful and relational parts and then were coded in line with the main research objective. The workplaces had the following symbols: nationalistic symbols (Turkish flag, Syrian Flag, Sultan's signatures, maps, etc.), religious and traditional symbols (photographs, verses, evil eyes, incenses, miniatures, etc.), and gender symbols (photos of football games, prayer beads, etc.).

The symbols in the workplaces predominantly correspond to communal personalization. The family photos, maps of regions of origin, miniatures, and pictures in almost all workplaces were examples of communal personalization. The religious/traditional and nationalistic symbols in the workplaces indicate that the participants try to chart territory for themselves. They use those symbols to create a defensible space and cross the symbolic boundaries between the locals and themselves. The elaborate Turkish flags and Sultan's signatures in their workplaces are significant identity obsessions that they use to cross the "symbolic boundaries" between themselves and the locals. The religious and cultural objects/scriptures (verses, prayers, evil eyes, etc.) in the workplaces point to the participants' attempt to establish a bond with the dominant Muslim-Turkish culture in the region.

The participants' efforts to create communal personalization and a defensible space through symbols in their workplaces indicate that space contains a rich body of belongingness with different sociocultural and political engagements. Leaving one's mark on space is a way of dropping anchor off the time and the new "home" through collective memory and symbols. The Interview and observational data remind us that we need to consider the dynamic relationship between macro and micro levels to better understand how refugees adopt the way of living in the host country because integration into everyday life is not only about personal relations but also about codes, myths, and emotions bounded by social, cultural, and historical ties. It is clear that observing and evaluating refugees' strategies to adapt to everyday life and tracing their individual experiences play a crucial role in integration processes. The participants' statements dramatically show that they have no hope of returning to Syria. However, this does not mean that they will never have a new "home." Therefore, we should focus on their complex networks and communication tools, efforts to have a new "home," and biographical and emotional motives. 